\title{
Rewriting history through proteins
}

\author{
Today, researchers interested \\ in exploring ancient samples \\ and remains at the molecular \\ level mainly rely on DNA. But \\ proteins might tell us even more \\ about history. Andrew Wiecek \\ examines how protein analysis \\ techniques are shedding new \\ light on Inca history.
}

At age 15, she was determined to be a rare example of physical and spiritual perfection, and therefore chosen for sacrifice. Preparations began a year beforehand during which time she was confined to a closed house within the Inca capital of Cusco and fed a rich diet of maize and llama meat. She then traveled more than 1200 miles to the snowy summit of the volcanic Mount Llullaillaco. Consuming an intoxifying meal of caco leaves washed down with maize beer, she quickly fell asleep only to be covered with volcanic ash and left to die.

Well, at least, that's the story according to Spanish explorers. However, forensic anthropologist Angelique Corthals, an assistant professor at the Stony Brook University School of Medicine and director of Stony Brook's BioBank, isn't quite so sure. But to piece together what was really happening during those final days, Corthals and her team would have to travel back in time, using the latest in proteomics technology to analyze proteins from the young girl's mummified remains. Corthals' efforts would provide a surprising molecular snapshot into the world of this doomed child.

\section{0 years later}

In 1996, a group of archaeologists uncovered the remains of what appeared to be the 15-year old Inca girl along with two younger children, a boy and a girl, on Mount Llullaillaco. The cold temperatures and volcanic ash had actually protected their bodies from decomposition. Nicknamed "the maiden," the archaeolo- gists performed radiocarbon dating and genomic analysis to learn more about who this teenage girl was and whether or not she might have been sacrifice victim from the explorer's stories (1).

The research team's carbon dating data indicated that "the maiden" died around 500 years ago, in agreement with the stories, while dietary isotopic data detected a sudden shift in diet during her final year of life, moving toward rich animal protein. Analysis of mitochondrial DNA samples also defined her haplogroup, further confirming the carbon dating data, and strongly indicating that this mummy was, in fact, the sacrifice victim.

But Corthals, who is also part archeologist and part biomedical researcher, knew this genomic analysis was only scratching the surface of the potential molecular information these samples held. While sequencing ancient DNA can be used to get a list of genes and specific mutations for a given individual, it says nothing at all about how or when those genes are expressed in cells. In contrast, if one were to analyze the proteome, a cell's protein composition, this could actually provide a clearer window into what was physiologically happening when "the maiden" died.

"That's the beauty of proteins, they basically indicate what the individual is expressing at the time of sampling," says Corthals. This means that if you sample a person's proteome today and then resample in a month, the profiles would be different, the result of changes in gene expression in response to external conditions such as disease or diet or something else.

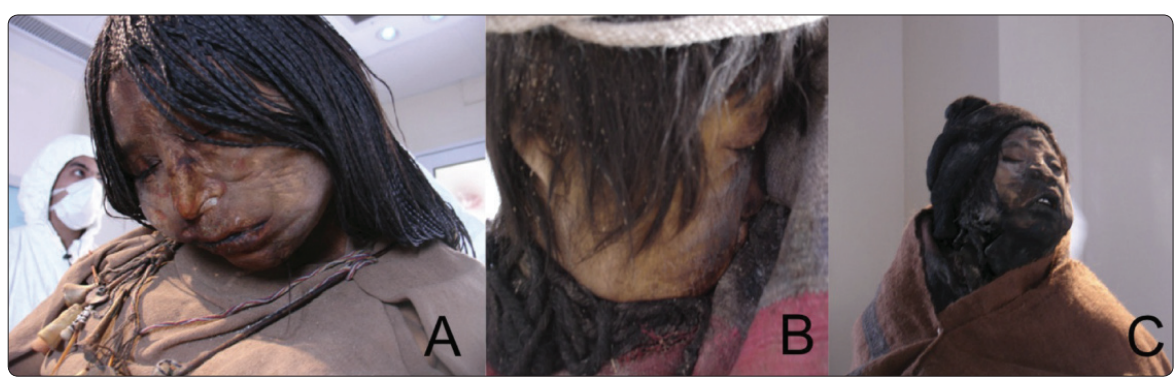

In 1999, archeologists found the preserved remains of three children who were sacrificed on Mount Llullallaico. Source: PLoS One
A clearer example of this can be seen when researchers discover pathogen DNA in an ancient sample. They can compare the ancient and the modern versions of the pathogen at the nucleotide level to determine the "age" of the pathogen, or the specific subtype of pathogen in the sample. But the presence of that pathogen DNA, even if it is determined by sequence analysis to not be contamination, doesn't necessarily mean the individual was infected by the pathogen or that their death was a result of the pathogen.

In order to figure those things out, researchers would need to analyze the immune response of the host at the time of death; experiments that require specialized tools and methods capable of analyzing the abundance of proteins involved with, and regulated by, the immune response from limited samples that are hundreds to thousands of years old.

\section{Further back in time}

At the Natural History Museum of Denmark, postdoctoral fellow Enrico Cappellini studies both ancient DNA and ancient proteins. Like Corthals, he believes ancient proteomics is a strong complement to ancient DNA studies.

From a technical standpoint, there is an advantage to working with ancient proteins: some proteins don't degrade as quickly as DNA. While it is currently difficult to recover DNA from samples that are more than 500,000 years old, collagen - an abundant protein that makes 
up connective tissue in vertebrates-has been recovered from samples that are up to 1 million years old.

Of course, not all proteins are as stable and abundant as collagen, and not all samples are preserved in conditions that reduce potential environmental damage. As such, even though researchers have been studying ancient proteins for more than 20 years, successes have been limited to analyzing only a small number of abundant proteins. But this could be changing with the rise of new instruments and protein preparation methods.

In a paper published last year in the Journal of Proteome Research (2), Capellini and colleagues analyzed 126 unique proteins from a 43,000-year-old woolly mammoth. "We showed it was possible to go from a very few common proteins, something boring like collagen, to something more interesting like albumin," explains Capellini. Albumin is a protein that helps transport other biomolecules through the bloodstream of a mammal.

A typical proteomics workflow consists of three separate steps: sample preparation, mass spectrometry, and data analysis. At first, protein samples are purified and separated into smaller fractions using chromatography methods that include liquid and gas-based separation. This step can in many ways be thought of as a "pre-screen," enabling researchers to separate the components of the complex mixture to enhance mass analysis and also provide some initial information on protein composition prior to more directed analysis. Next, the

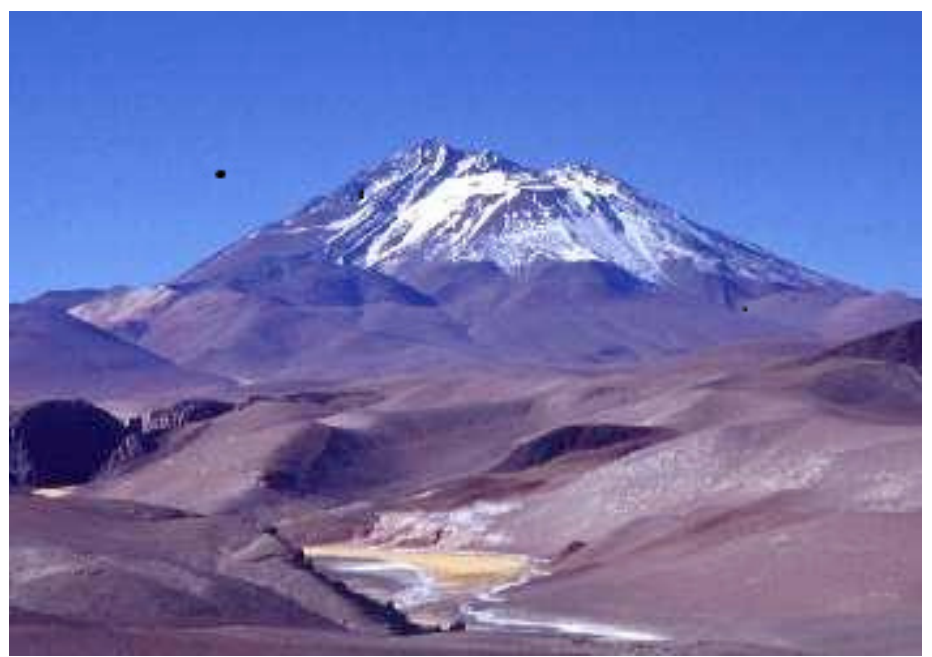

Mount Llullaillaco was the site of Inca riutal sacrifices.

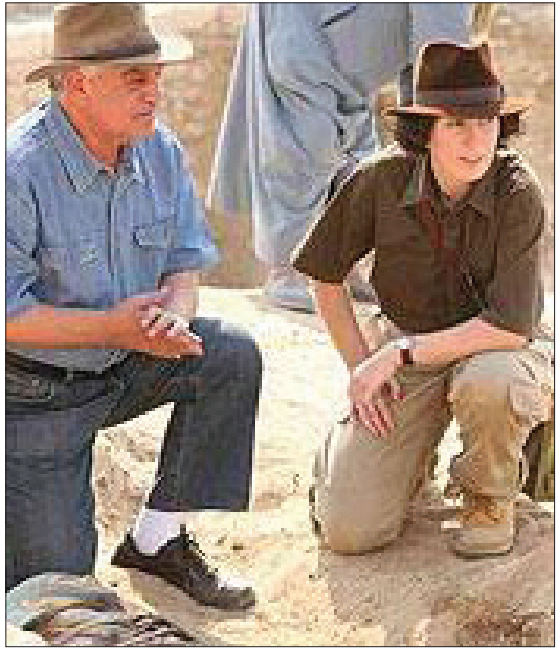

Angelique Corthals (right) is part archeologist, part biomedical researcher. Source: Millsaps College

protein fractions are analyzed by mass spectrometry. Here, the proteins and peptides are first ionized and then the

resulting fragments introduced into a machine that collects data on ion masses. Finally, the mass spectra obtained from the mass spectrometer are compared with a database of known peptide masses to identify the protein components within the sample.

One key to Capellini's success in analyzing such a wide range of ancient proteins from the mammoth was to limit loss during sample preparation. In contrast to modern protein studies where more cells can be grown or experiments repeated, ancient samples are always limited and therefore Capellini's team had to modify several steps in the traditional proteomics workflow, such as eliminating precipitation steps during sample preparation to reduce the loss of cross-linked proteins.

"This is a very exciting time to get into ancient protein [analysis] because the technological developments that are coming out on a yearly basis are opening up a lot of possibilities," says Capellini.

\section{Techniques age quickly}

Altering traditional workflows is not the only concern for researchers working with ancient samples - contamination will always be an issue with these samples. And when it comes to ancient protein analysis, keratin, a structural protein that makes up human skin, hair, and nails, is a common contamination culprit.

To combat keratin contamination, most proteomics labs follow strict protocols. For example, Corthals' lab fractionates peptides using liquid chromatography rather than gel electrophoresis. In gel-electrophoresis, proteins must be removed from a lysis solution, resolved on an electrophoresis gel, and then returned to a solution prior to MS analysis. On the other hand, liquid chromatographybased fractionation keeps proteins in a single solution, reducing the possibility of contamination.

Downstream, the data analysis software used to identify peptides and proteins from MS data has greatly improved over the years. With the expansion of MS spectra databases as more proteomics studies are completed, as well as the creation of new algorithms developed by mathematical biologists to extend mass analysis, peptide identification programs are more accurate and make less falsepositive identifications. "That's not trivial," says Corthals. "Those people are the unsung heroes because no one wants to hear about the programming."

But the expansion of databases with new spectra and growth of MS analysis tools does bring up a quandary for those working with ancient proteins: what spectral databases do you search when examining ancient samples? For the woolly mammoth study, Cappellini and colleagues searched against a protein analysis of its modern ancestor, the elephant. And while a search against a high-quality mammoth genome could have potentially also identified new isoforms or similar enzymes with different functions, that genome was published 
in 2008-one of the first examples of sequencing ancient DNA-and only done to 0.7 -fold coverage (3).

"We weren't able to do anything with that," says Capellini. "But no one is going to embark on the mammoth genome sequencing because it's already been published. It's not rewarding from a publication exploitation point of view. So, we had to rely on modern stuff."

But all the latest techniques to study ancient proteins might already be, well... ancient. Since his woolly mammoth study, Capellini's team has replaced the mass spectrometer that they used with a new MS system possessing both increased sensitivity and mass accuracy.

"We changed almost everything," says Capellini. He reservedly notes (this work is not yet published) that for sample preparation, they continue to improve ways to minimize losses and improve recovery especially in the demineralization and digestive steps. "The main point here is we're not throwing anything away."

\section{Not so perfect after all}

Armed with these advanced protein analysis tools and methods, Corthals realized it was time to learn more about what happened during those final days for the15-year-old Inca maiden.

The remains of the maiden and her two younger companions are stored at $-20^{\circ} \mathrm{C}$ in the Museum of High Mountain Archaeology in the city of Salta, Argentina, close to Mount Llullaillaco. Corthals convinced the archeologists to let her take a sample; in the end she was allowed to take three samples: a piece of blood-soaked cloth from the boy and cotton swabs from the lips of the maiden and the boy. Returning to her New York lab, Corthals and her team carefully handled their precious samples, using strict protocols to process the materials for analysis using a liquid chromatography tandem MS LTQ-Orbitrap system.

The results, reported in an article published earlier this year in the online journal PLoS One (4), describe the first use of "shotgun proteomics" to detect proteins involved in the anti-bacterial immune response in an ancient sample. As it turns out, the two Inca children - selected because they represented an idealized state of humanity, according to Spanish explorers - were, in fact, battling chronic lung infections.

"It calls into question, first of all, the idea of perfection, in terms of that these children need to be perfect," says Corthals. "It also calls into question these secondary sources, which are the only sources we have of the Inca empire because they didn't have writing. And it opens a whole new field of questions of what was happening [at that moment], making things a little more exciting than we thought they were."

In the end, Corthals believes that there might be plausible explanations for their findings. For instance, the children might have acquired infections sometime during the months of preparation for the ritual sacrifice, possibly the result of being confined to a closed house with an open fire. Such a smoky environment could have irritated the lungs, allowing for an opportunistic infection. Another possibility is that the infection could have ben obtained during the 1200-mile journey from Cusco to Mount Llullaillaco. "It's the equivalent of walking from Mexico to the Canadian border. For a 15-year-old, that's pretty tough," says Corthals.

Moving beyond the Incas, the next step for shotgun proteomics of ancient samples will likely be the use of even older or more damaged samples. In fact, Corthals already has a target in mind here: the frozen corpse of a 1918 Spanish flu victim. "Everybody's been studying the Spanish flu virus to death, but nobody's been actually looking at the immune response," says Corthals. But that trip back in time will have to wait its turn.

\section{References}

1. Wilson, A. S., T. Taylor, M. C. Ceruti, J. A. Chavez, J. Reinhard, V. Grimes, W. MeierAugenstein, L. Cartmell, B. Stern, M. P. Richards, M. Worobey, I. Barnes, and T. P. Gilbert. 2007. Stable isotope and DNA evidence for ritual sequences in inca child sacrifice. Proceedings of the National Academy of Sciences 104(42):16456-16461.

2. Cappellini, E., L. J. Jensen, D. Szklarczyk, A. Ginolhac, R. A. da Fonseca, T. W. Stafford, S. R. Holen, M. J. Collins, L. Orlando, E. Willerslev, M. T. Gilbert, and J. V. Olsen. 2011. Proteomic analysis of a pleistocene mammoth femur reveals more than one hundred ancient bone proteins. Journal of Proteome Research 11(2):917-926.

3. Miller, W., D. I. Drautz, A. Ratan, B. Pusey, J. Qi, A. M. Lesk, L. P. Tomsho, M. D. Packard, F. Zhao, A. Sher, A. Tikhonov, B. Raney, N. Patterson, K. Lindblad-Toh, E. S. Lander, J. R. Knight, G. P. Irzyk, K. M. Fredrikson, T. T. Harkins, S. Sheridan, T. Pringle, and S. C. Schuster. 2008. Sequencing the nuclear genome of the extinct Woolly Mammoth. Nature 456(7220):387-390.

4. Corthals, A., A. Koller, D. W. Martin, R. Rieger, E. I. Chen, M. Bernaski, G. Recagno, and L.M.
Dávalos. 2012. Detecting the immune system response of a 500 Year-Old inca mummy. PLoS ONE 7(7):e41244.

Written by Andrew S. Wiecek. [G6⿴囗十

BioTechniques 54:19-21 (January 2013)

doi: $10.2144 / 000113975$

To purchase reprints of this article, contact:

biotechniques@fosterprinting.com 